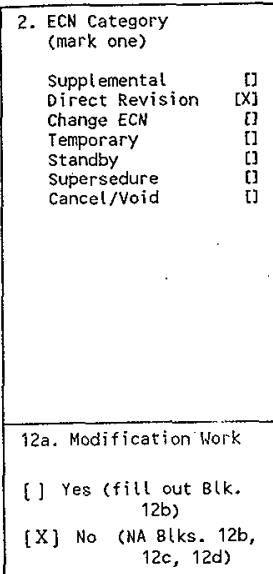

13a. Description of Change

3. Originator's Name, Organization, MSIN, and relephone No.

Treah Nuxall, SNF CVD, R3-47, $372-3739$

6. Project Title/No./Work Order No.

Spent Nuclear Fuel Cold Vacuum Drying

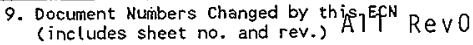
NF-3876, SNF-3877, SNF-3878, SNF-3879, SNF-

3880 , SNF-3881, SNF-3882, SNF-3883, SNF-3884,

SNF-3886, SNF-3887, SNF-3888, SHF-3890, SHF-

3891 SNF-3892, SNF-3893, SNF-3894, SNF-3895,

SNF-3920, SNF-3921, SNF-3922, SNF-3923, SNF-

3924 SNF-3925 SNF-3926, SNF-3927, SNF-3928,

SNF-3929, SNF-3930, SNF-3931, SNF-3932, SNF-

3933, SNF-3934, SNF-3935, SNF-3936

12b. Work Package $12 \mathrm{c}$. Modification Work Complete No.

N/A

$\mathrm{N} / \mathrm{A}$

Design Authority/Cog. Engineer signature \& Date

13b. Design Baseline Document?

[] Yes

[X] No

Revision to meet SEL, Rev, 6 .

14a. Justification (mark one)

As-Found [] Facilitate Const

[]

Const. Error/Omission

Design Error/Omission

[]

14b. Justification Details

Revision to SEL.

15. Distribution (include name, MSIN, and no. of copies)

ser attachel diotributain
RELEASE STAMP

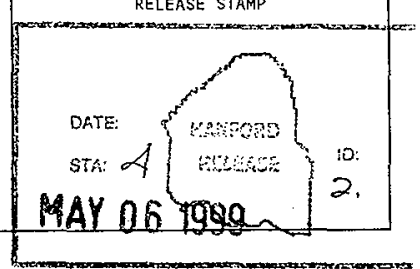




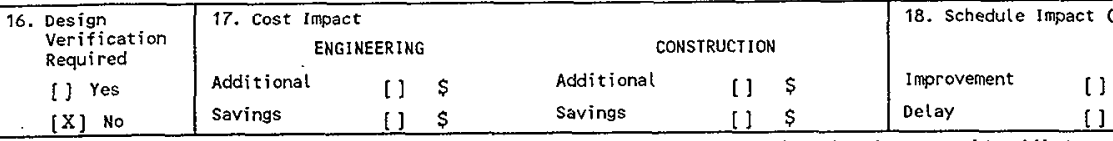

19. Change Impact Review: Indicate the related documents (other than the engineering documents identified on side 1 ) that will be affected by the change described in Block 13 . Enter the affected document number in Block 20.

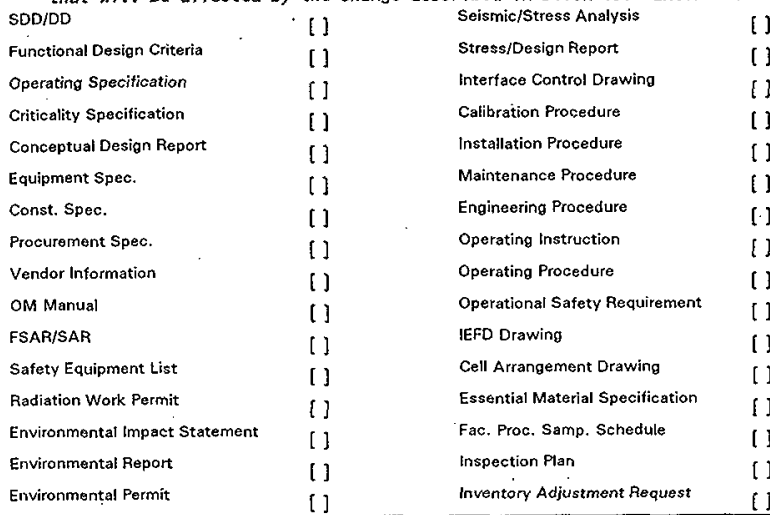

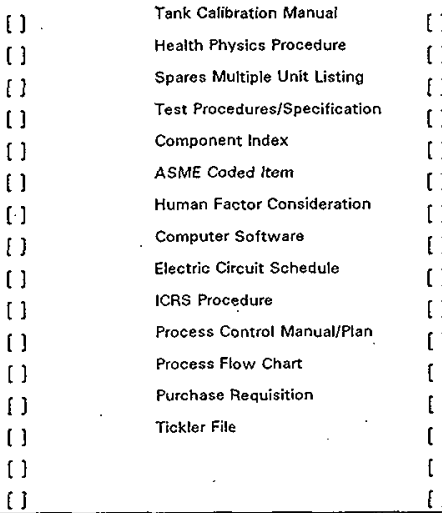

20. Other Affected Documents: (NOTE: Documents listed below will not be revised by this ECN.) Signatures below indicate that the signing organization has been notified of other affected documents listed below. Document Number/Revision Document Number/Revision

Document Number Revision

$$
\mathrm{N} / \mathrm{A}
$$

21. Approvats

Design Authority

Designated Cog. Eng.

Authorized Rep. Mgr.

$a A$

other R. Whitehurst

sathety(inaclear)

$$
\text { Signature }
$$

c. Miska CRMh

c. Van Katwijk Pton \& 1. chono 5 Bar foy te $4 / 27 / 99$

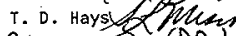

Lim 8 (DA) gommxisuan

\section{Date}

$4 / 27 / 99$

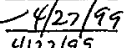
$4127 / 99$ $\therefore \quad 5 / 4 / 99$
Signature

Date
Design Agent

\section{$P E$}

QA

Safety

Design

Environ.

other

\section{DEPARTMENT OF ENERGY}

sisnature or a Control Number that

tracks the Approval Signature

ADOITIONAL
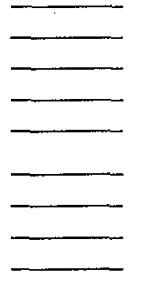


\title{
FIKE SCHe PURGE SUPPLY PRESSURE SAFETY ELEMENT
}

\author{
Carl Van Katwijk \\ Numatec Hanford, Richland, WA 99352 \\ U.S. Department of Energy Contract DE-AC06-96RL13200 \\ EDT/ECN: 653776 UC: 620 \\ Org Code: $2 \mathrm{G} 300$ \\ B\&R Code: 39EW40400 \\ Charge Code: $105559 / \mathrm{A} 000$ \\ Total Pages: 14
}

Key Words: Fike SCHe Purge Supply Pressure Safety Element

Abstract: Fike SCHe Purge Supply Pressure Safety Element

TRADEMARK DISCLAIMER. Reference herein to any specific commercial product, process, or service by trade name, trademark, manufacturer, or otherwise, does not necessarily constitute or imply its endorsement, recommendation, or favoring by the United States Government or any agency thereof or its contractors or subcontractors.

Printed in the United States of America. To obtain copies of this document, contact: Document Control Services, P.O. Box 950, Mailstop H6-08, Richland WA 99352, Phone (509) 372-2420; Fax (509) 376-4989.

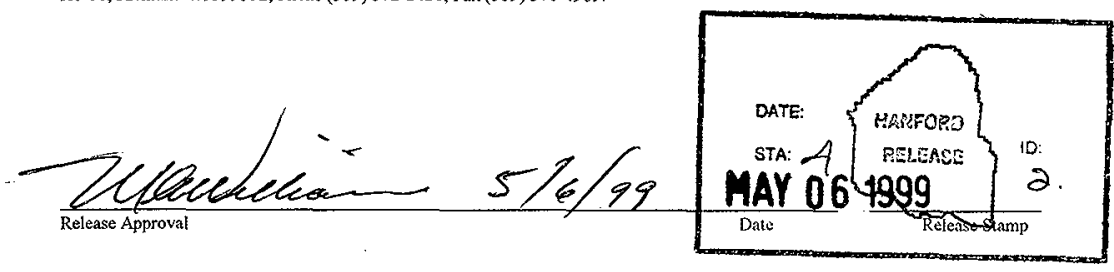

\section{Approved for Public Release}


(2) Title

FIKE SCHE PURGE SURELY PRESSURE SAFETY ELEMENT

Change Control Record

(3) Revision

1 RS
(4) Description of Change - Replace, Add, and Delete Pages

REVISION TO MEET SEL REV. 6, ECN 653776
Authorizeqfor Release

(5) Cog. Engr. $/$ (9) Cog. Mgr) Date

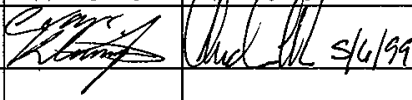


Commercial Grade Item Upgrade Dedication Form

ECN No. NA CGI No. CGI-SNF-D-13-P5-023

SNF-3920, Rev. 1

Title: FIKE SCHE PURGE SUPPLY PRESSURE SAFETY ELEMENT

\begin{tabular}{|c|c|c|c|}
\hline Item No:: NA & Manufacturer. & & Supplier: \\
\hline Mfg. Part/Model No.: & & Supplier's PIN: & \\
\hline
\end{tabular}

Part Description:

End Use Description:

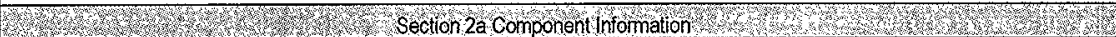

\begin{tabular}{l|l|l|l} 
Equipment No:: SCHe- & Specification No.: W-441. & Manufacturer: FIKE & Past P.O. No.: NA
\end{tabular}

PSE-5*05, 5*24,

$5 * 44,5 * 64$.

Procurement and/or Model

No:: CPV-ST-1/2"

P5, Rev. 2

Page 1 of 12

W/1/2-30SM-10-

316SS

Component Description: These pressure safety elements are $1 / 2$ inch rupture discs used to prevent an overpressure condition in the helium supply lines or the MCO. The pressure safety elements are located in the supply lines between the pressure regulating valves at the SCHe supply bottles and the pressure reducing valves supplying the helium purge.

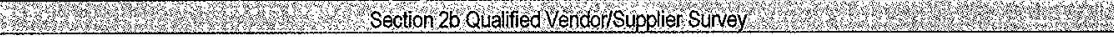

1. Is the Item available from a catalogue of a qualified NQA1 supplier? (coordinate with project CGI interface Engineer or BTR)

[ ] YES (go to \#2 below)

[X] NO (go to procedure step 5.3.2, proceed to dedicate Item.)

If not available from a qualified NQA1 supplier, is it available from an ISO 9000 supplier? (coordinate with project CGI

interface Engineer or BTR)

I ] YES (go to \#2 below, then go to procedure step 5.3.2, proceed to dedicate Item)

[X] NO (go to procedure step 5.3.2, proceed to dedicate ltem.)

2. List of Candidate qualified suppliers or ISO 9000 suppliers

company name and type contact name phone

NA

3. Recommended Procurement Strategy (coordinate with project CGI interface Engineer or BTR):

NA

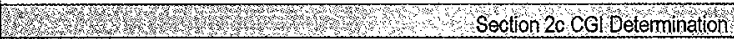

1. Question \#1: Is the ltem subject to design or specification requirements that are unique to nuclear facilities or activities?

1 ] YES (the Item is not commercial grade)

$[\mathrm{X}] \quad$ NO (continue) 
Title: FIKE SCHe PURGE SUPPLY PRESSURE SAFETY ELEMENT

2. Question \#2: is the Item used in applications other than nuclear facilities or activities?

[ ] NO (the item is not commercial grade)

[X] YES (continue)

3. Question \#3: Is the Item ordered from manufacturer/supplier on the basis or specifications set forth in the

$$
\text { published product information (e.g., manufacturer's catalog)? }
$$

[ ] NO (the ltem is not commercial grade)

[X] YES (continue)

[X] All three criteria have been satisfied. The ltem meets the definition of commercial grade.

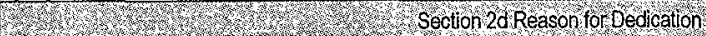

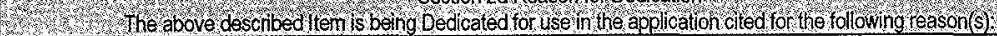

[X] Item is being purchased from a non ESL manufacturer supplier as commercial grade to be used in a Safety Class application.

[ ] Item is being purchased from a non ESL manufacturer supplier as commercial grade to be used in a Safety Significant application.

1 I Item was purchased from a non ESL manufacturer supplier as commercial grade to be used in a Safely Class application.

[ ] I Item was purchased from a non ESL manufacturer supplier as commercial grade to be used in a Safety Significant application.

1 1 Other ('like-for-like', similar, substitution, replacement evaluation)

7.

A. Part/Component Safety Function:

1. Preclude MCO overpressurization and support the SCHe purge availability to the MCO by protecting the purge lines from possible overpressure from the helium supply bottles.

2. Pressure Boundary Integrity-Prevents helium leakage from the normal Helium System or the $\mathrm{SCHe}$ System or air leakage into the system during vacuum operation.

3. Maintain critical function before and after Seismic event.

B. Part/Component Functional Mode:

Safety Function \#1:

[X] Active - Mechanical or Electrical change of state is required to occur for the component to perform its safety function

[ 1 Passive - Change of state is not required for the component to perform its safety function Safety Function \#2:

[ ] Active-Mechanical or Electrical change of state is required to occur for the component to perform its safety function.

[X] Passive - Change of state is not required for the component to perform its safety function Safety Function \#3:

[ ] Active - Mechanical or Electrical change of state is required to occur for the component to perform its safety function.

[X] Passive - Change of state is not required for the component to perform its safety function 
Title: FIKE SCHe PURGE SUPPLY PRESSURE SAFETY ELEMENT

C. Host Component Safely Function (if applicable): NA

1.

D. Failure Mechanisms(s) and the effects on component or system safety function (see worksheet 1):

1. Failure of the disc to rupture at its nominal burst pressure.

2. Fracture of the disc housing or piping attachment.

3. Disc ruptures or leaks past disc at a lower pressure than its nominal burst pressure.

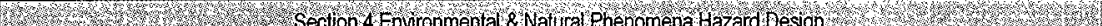

Environmental Qualification Required:

Yes [ ]

If yes: Environmental Qualification Requirements

No $[\mathbf{X}]$

Limiting Environmental Conditions:

Environmental Condition B

Required Safety Functions:

al Phenomena Hazard (NPH) Design Required:

Qualification Period:

Natural Phenomena
Yes [X]

No $[$ ]

HNF-PRO-97, Rev. 0

If yes: NPH Design Requirements

W-441-P5, Rev. 2

Performance Category: PC-3

NPH Design Req'ts.: Seismic Condition A

Required Safety Functions.' Disc ruptures to relieve overpressure in the helium supply lines;

Pressure Boundary Integrity.

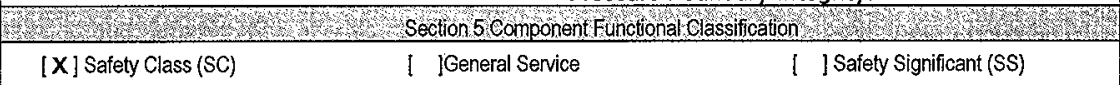

If part/component classification is different from host component/system, document basis.

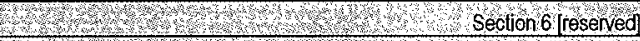

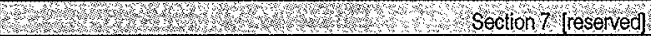

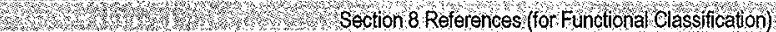

National Codes/Standards:

Safety Analysis Report (SAR): HNF-SD-SNF-SAR-002,

Rev. 4A

Drawings: H-1-82165, Rev. 2

HNF-SD-SNF-SEL-002, Rev. 6 CVDF-SSD-003

Vendor Manuals/Manufacturer/Supplier Information: Fike Rupture Disc Application, Selection, and Specification, HOV Series

Other: 


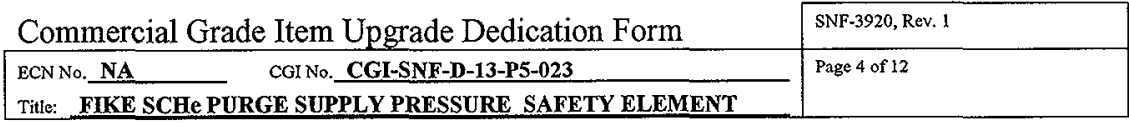

\begin{tabular}{|c|c|c|c|c|}
\hline \multicolumn{5}{|c|}{ 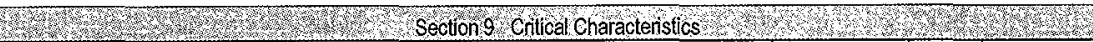 } \\
\hline $\begin{array}{l}\quad \text { Critical Characteristios } \\
\text { Verification Document:: Vendor } \\
\text { Specifications, } \\
\text { HNF-SD-SNF-SEL-002, Rev. } 6\end{array}$ & Acceptance Criteria/Tolerances & $\begin{array}{l}\text { Acceptance } \\
\text { Method }\end{array}$ & 10 & Function \\
\hline \multicolumn{5}{|c|}{ 1. Item Identification Critical Characteristics (necessary for reasonable assurance that the Item delivered is the Item specified) } \\
\hline $\begin{array}{l}\text { Component Number-Procurement } \\
\text { and/or Model Number }\end{array}$ & $\begin{array}{l}\text { CPV-ST-1/2" W/1/2-30SM-10- } \\
316 \text { SS , (Per Procurement } \\
\text { Package W-441-P5, Rev. 2, } \\
\text { Section G, Design Data Sheet) }\end{array}$ & $1, \mathrm{IN}$ & $\mathrm{x}$ & \\
\hline Nameplate - Manufacturer & Fike & $1,1 \mathrm{~N}$ & $\mathbf{X}$ & \\
\hline Process Connection & $1 / 2$ Inch NPT & $1, \mathrm{IN}$ & $\mathbf{x}$ & \\
\hline \multicolumn{5}{|c|}{ 2. Physical Critical Characteristics (necessary for reasonable assurance that the Item delivered is the ltem specified) } \\
\hline Material, Housing & Stainless Steel (Note 4) & 1, IN $1, T$ & $\mathbf{x}$ & \\
\hline Material, Process Connection & Stainless Steel (Note 4) & 1, IN $1, T$ & $\underline{X}$ & \\
\hline Material, Rupture Disc & Urethane Coated Aluminum & 1, IN $1, T$ & $\mathrm{X}$ & \\
\hline \multicolumn{5}{|c|}{$\begin{array}{l}\text { 3. Performance Critical Characteristics (necessary \& sufficient for reasonable assurance that the Item will perform its intended } \\
\text { safety function(s)) }\end{array}$} \\
\hline Pressure Boundary Integrity & $\begin{array}{l}\text { No leakage at test pressure of } \\
165 \text { psig. Note } 3 .\end{array}$ & $1, \mathbf{T}$ & & $\mathbf{x}$ \\
\hline Leak Past Rupture Disc & $\begin{array}{l}\text { Pressure test to } 15 \mathrm{psig} \text {, } \\
\text { leakage to bubble tight } \\
\text { standards }<10-3 \mathrm{ml} / \mathrm{sec} \\
\text { Note } 5\end{array}$ & $1 . T$ & & $\mathbf{x}$ \\
\hline Rupture Disc Burst Pressure & Nominal 125 psig & $1, T$ & & $\mathbf{x}$ \\
\hline Environmental & Note 1 & & & \\
\hline Seismic Condition A & Note 2 & $1, T$ & & $\mathbf{x}$ \\
\hline \multicolumn{2}{|c|}{$\begin{array}{l}\text { 4. Notes and Legend: } \\
\text { 1. The pressure safety element and rupture disc are not } \\
\text { subject to degradation at environmental conditions of } 40^{\circ} \mathrm{F} \\
\text { and } 60 \% \mathrm{RH} \text { or } 115^{\circ} \mathrm{F} \text { and } 22 \% \mathrm{RH} \text { and are suitable for } \\
\text { Condition B application. } \\
\text { 2. Maintain critical function before and after Seismic event. W- } \\
441-\mathrm{P5} \text {, Rev. } 2 \text {, Appendix I, page } \mathrm{I}-2 \text {, provides a seismic } \\
\text { testing plan for these components at a seismic spectra TBD. } \\
\text { Equipment that has been shaker-table tested should not be } \\
\text { installed in a plant (Ref. IEEE Standard } 344-1984 \text {, Section } 7 \text { ). } \\
\text { Consequently, the seismic test constitutes a destructive test. }\end{array}$} & \multicolumn{3}{|c|}{$\begin{array}{l}\text { Acceptance Method: } \\
\text { 1. Special Test and Inspection } \\
\qquad 1, I N \text { for Inspection } \\
1, T \text { for Test } \\
\text { 2. Commercial Grade Survey } \\
\text { 3. Source Verification } \\
\text { 4. Vendor/ltem History }\end{array}$} \\
\hline
\end{tabular}




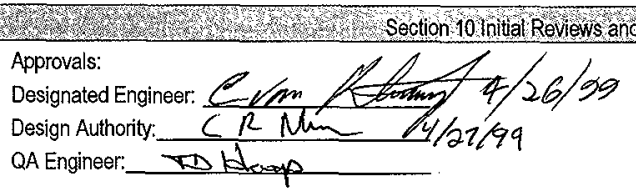




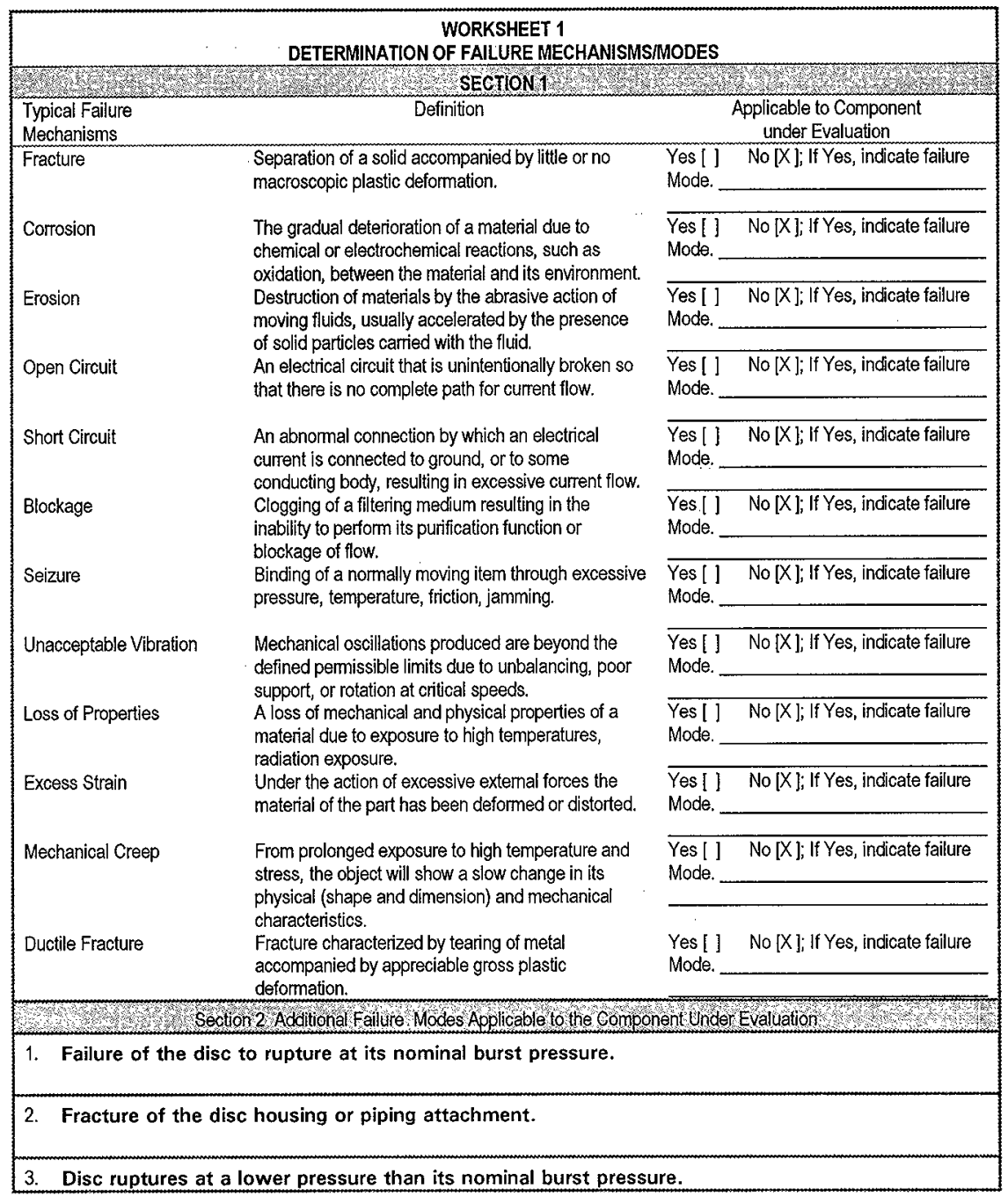




\section{CHECKLIST 1}

\section{ACCEPTANCE METHOD 1}

SPECIAL TEST/INSPECTION VERIFICATION

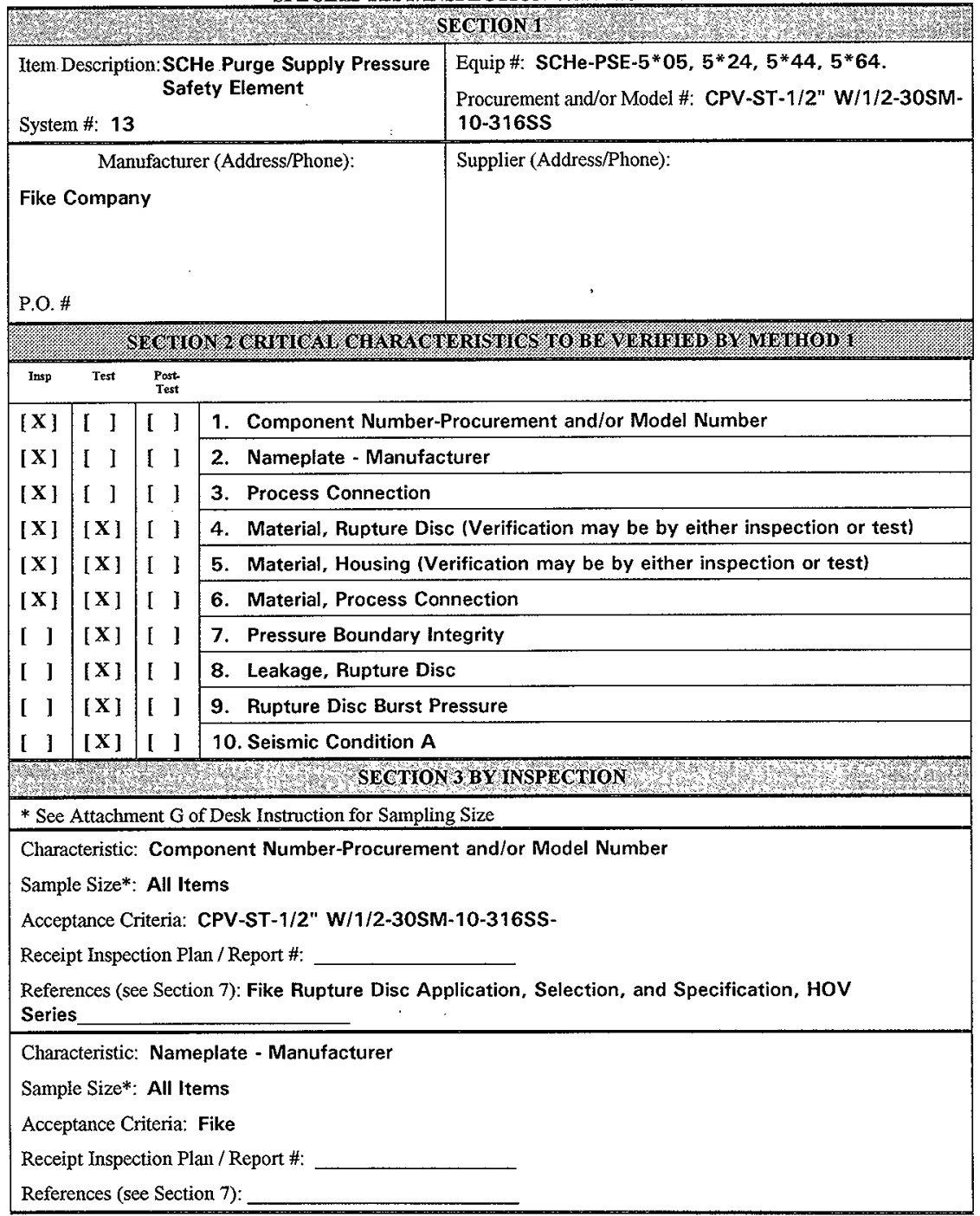




\author{
Characteristic: Process Connection \\ Sample Size*: All Items \\ Acceptance Criteria: 1/2 Inch NPT \\ Receipt Inspection Plan / Report \#: \\ References (see Section 7): \\ Characteristic: Material, Housing \\ Sample Size*: Normal Sampling Size \\ Acceptance Criteria: Stainless Steel \\ Receipt Inspection Plan / Report \#: \\ References (see Section 7):
}

Characteristic: Material, Process Connection

Sample Size*: Normal Sampling Size

Acceptance Criteria: Stainless Steel

Receipt Inspection Plan / Report \#:

References (see Section 7):

Characteristic: Material, Rupture Disc

Sample Size*: This is a destructive test since the coating must be damaged to test the material. Utilize the disc that has been ruptured for the burst pressure test to test the material. Test only one item.

Acceptance Criteria: Urethane Coated Aluminum

Receipt Inspection Plan / Report \#:

References (see Section 7):

17. 7 SECLION 4 BY SPECAAL TEST

* See Attachment G of Desk Instruction for Sampling Size

Test To Be Performed by:

[ ] Purchaser

[ ] Supplier/Manufacturer**

Number of Items to be Tested:

Test/Inspection Location:

[ ] Other

Characteristic for Test: Pressure Boundary Integrity

Acceptance Criteria: No Leakage at Process Test Pressure of 165 psig

Sample Size*: Normal Sampling Size

Actual Test Value:

Test Plan and Report \#: References (see Section 7): 
ECN No. NA

CGI No. CGI-SNF-D-13-P5-023

Page 9 of 12

Title: FIKE SCHe PURGE SUPPLY PRESSURE SAFETY ELEMENT

Characteristic for Test: Leakage Past Rupture Disc

Acceptance Criteria: At $15 \mathrm{psig}$, Leakage to bubble type standards $<10-3 \mathrm{ml} / \mathrm{sec}$ (do not wet disc with liquid solution (e.g. Snoop)

Sample Size*: Normal Sampling Size

Actual Test Value:

Test Plan and Report \#: References (see Section 7):

Characteristic for Test: Rupture Disc Burst Pressure

Acceptance Criteria: Nominal 125 psig

Sample Size*: Destructively Test Only One Item. After burst, use this disc for material test.

Actual Test Value:

Test Plan and Report \#: References (see Section 7):

Characteristic for Test: Seismic Condition A

Acceptance Criteria: Maintain Critical Function Before and After Seismic Event

Sample Size*: W-441-P5, Rev. 2, Appendix I, page 1-2, provides the seismic testing plan for these components. The seismic testing is conducted for one complete panel with the components assembled on the panel and tested as a complete assembly. The test seismically qualifies the entire assembly, including mountings, piping, and components. The number of components tested is dictated by the panel assembly design.

Actual Test Value:

Test Plan and Report \#: References (see Section 7):

**If Supplier/Manufachurer or Other, Refer to CGI Checklist-2 for Support Information 


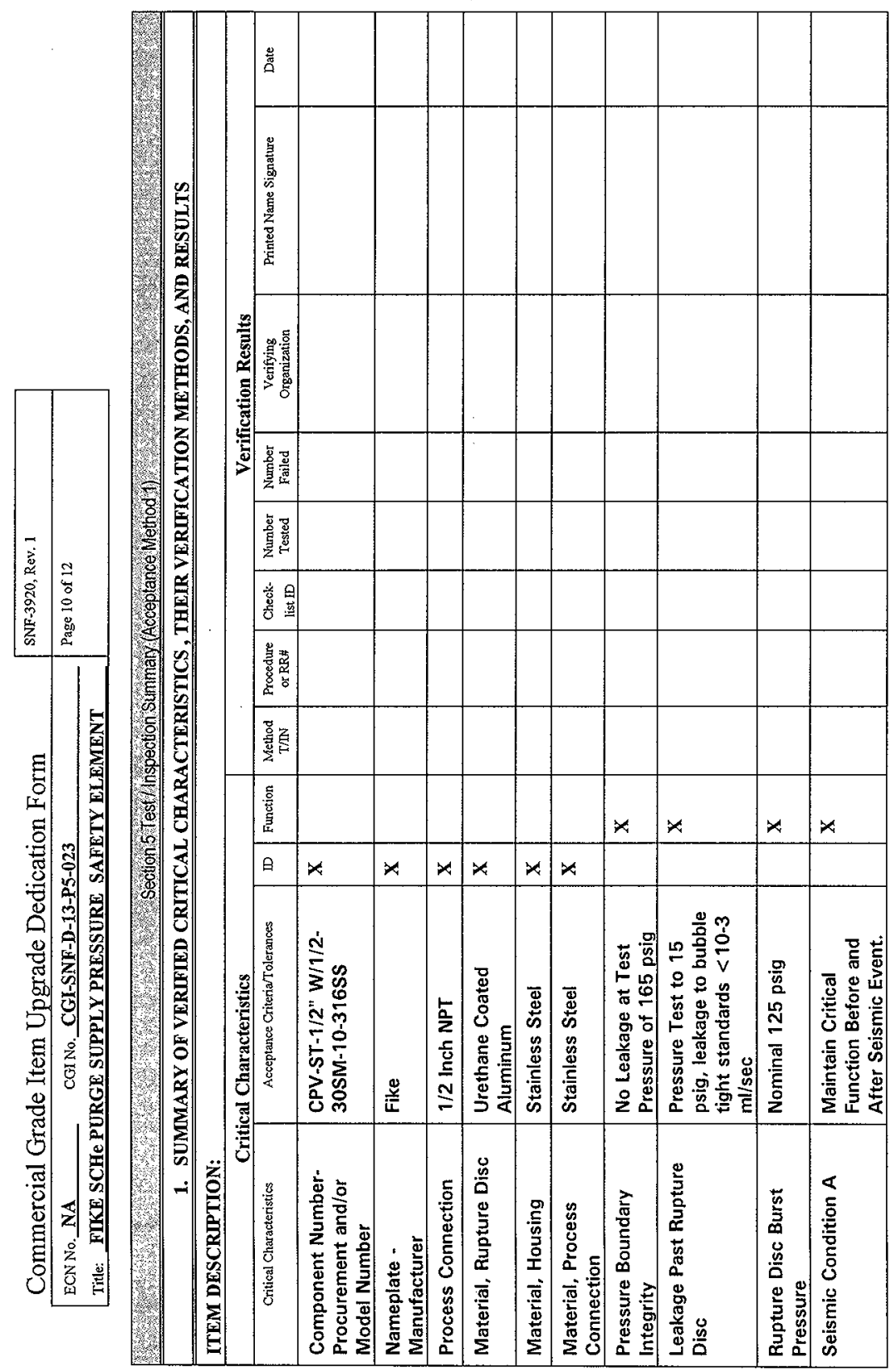




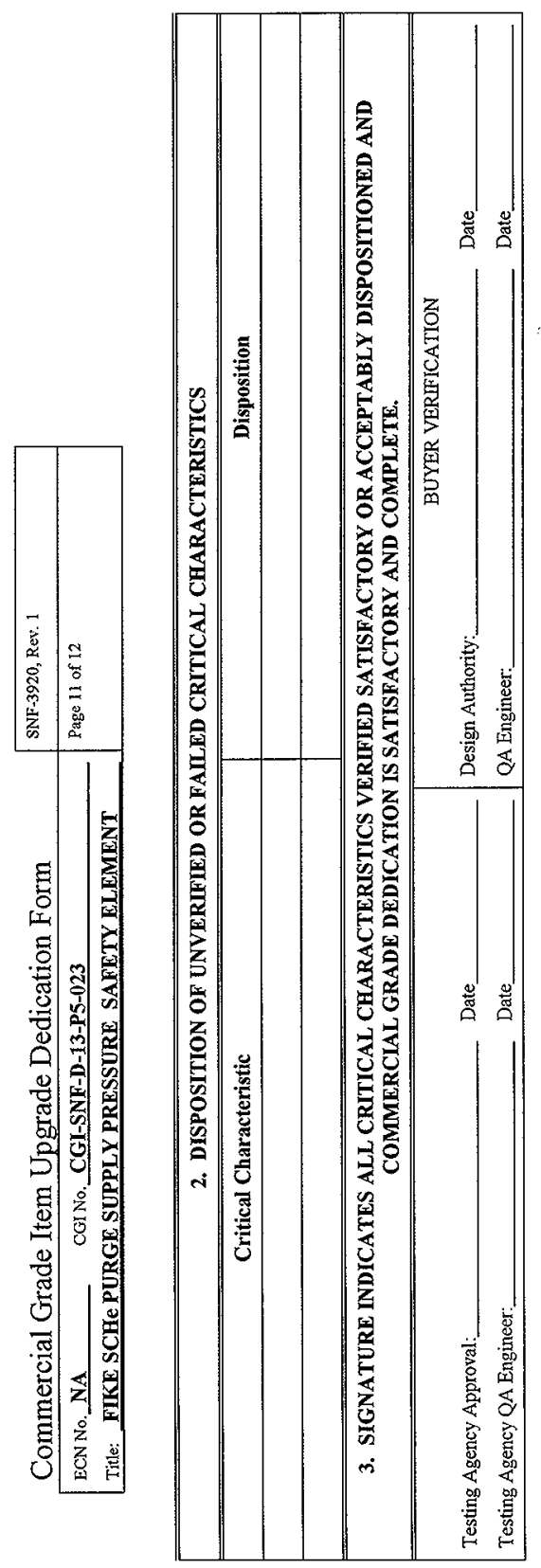


Commercial Grade Item Upgrade Dedication Form

ECN No. NA CGI No._CGI-SNF-D-13-P5-023
Title: FIKE SCHE PURGE SUPPLY PRESSURE SAFETY ELEMENT

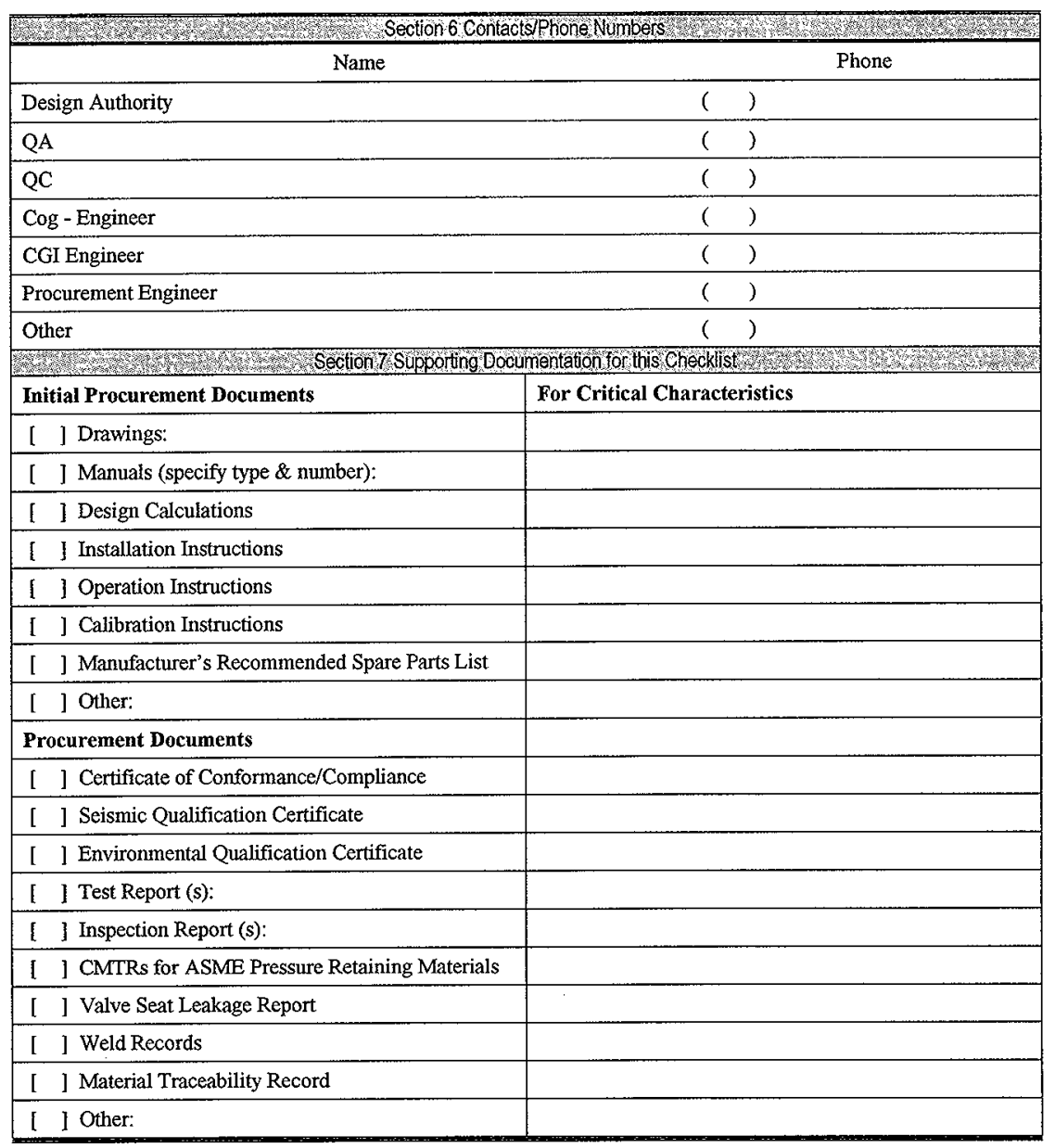

